\title{
5. The Russian Imperial Family as Symbol
}

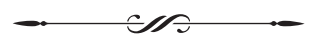

0 $\mathrm{n}$ the occasion of his coronation, Easter Sunday, April 5, 1797, Emperor Paul I issued two edicts that drew a close connection between the flourishing of the imperial family and the well-being of the state. He decreed his Law of Succession, then had it placed "for preservation" in an ark in the Assumption Cathedral. The law supplanted the Petrine rule of designation with an order of heredity succession. Paul sought to ensure "the tranquility of the State," to be "based on a firm law of inheritance upon which every right-thinking person is certain." A Statute of the Imperial Family, issued the same day, declared the "increase of the Sovereign family (Familiia)" one of the grounds for the "illustrious condition" of the state. Russia had experienced the principal blessing, "seeing the inheritance of the Throne confirmed in Our Family, which may the All-High perpetuate to eternity." The statute specified the estates and revenues to go to members of the family, the titles they held, and the rules of inheritance they would observe. It established an Appanage Department to manage the family's estates and income. ${ }^{2}$

The need to restore a reliable order of succession was widely understood in Russia during the second half of the eighteenth century. Leaving the succession to each ruler's discretion had put the throne at the disposition of the cliques in the court, particularly the guards' regiments. The turmoil accompanying each succession, it was clear, endangered the security of the state. Catherine II, herself a beneficiary of this situation, set about composing a new succession law, as early as 1766 . She remarked, in a draft of the statute that "the first and

\footnotetext{
$\overline{1 \quad \text { PSZ, sobranie }}$ 1, no. 17910, April 5, 1797.
}

$2 \quad$ PSZ, sobranie 1, no. 17906, April 5, 1797. 
fundamental law of this autocratic (samoderzhavnoe) rule issued and drafted by our imperial hand, should, by its essence, be the steadfastness of the throne and firmness in its inheritance." The project would have appointed Paul her successor and established an order of hereditary succession following the male line. Catherine returned to this question in 1785. A project of this year also provided for hereditary succession in the male line. Both projects contended that such a law was necessary to preserve the unity and indivisibility of the empire, the reason that Peter had cited in justification of succession by designation. ${ }^{3}$

However, Catherine did not issue a succession law. Indeed, hereditary succession, though preferable in principle, hardly suited the interests or tastes of Russian monarchs of the late eighteenth century. Even after Paul promulgated his law, it proved hard to follow, and neither he nor his firstborn son, Alexander, acted in a way to implant a firm or certain system of inheritance. A dynastic tradition could not be established by an edict alone; it required the elevation of family values and patterns of public conduct and these took hold in Russia only in the second quarter of the nineteenth century. The law could only have the desired effect when it corresponded to the principal symbols that the monarch used to represent his power. This paper will discuss the emergence of the imperial family as principal symbol of Russian monarchy as it was presented to the elite in ceremonies, literature, and visual representation-what I call a dynastic scenario.

The modes of behavior and representation that governed the imperial court until 1825 were consistent with the principles underlying Peter the Great's succession law of 1722 . The law stated the fundamental incompatibility between the principle of inheritance and Peter's own conception and practice of monarchy. Petrine absolutism was grounded on a principle of utility; the monarch's dedication to the well-being of the state justified his extensive authority. Peter's statutes proclaimed the submergence of the past, and the principle of hereditary monarchy could hardly withstand this razor. An ineffectual or destructive son was an obstruction to the goals of monarchy. The succession took on the features of an oedipal drama recounted in Alain Besançon's account of the bitter struggle ending in the death of Alexei Petrovich. Peter's second-born son, Peter Petrovich, had died in 1719, thereby depriving him of a male heir. The succession law projected the father-son

3 For a detailed discussion of the problem of succession, see article 2 in this volume.

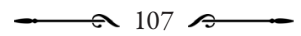


conflict into the next century. The son, possessed by "the malice of Absalom," was an ever-present threat to the throne, the greatest source of instability and a peril to the general good. These notions were formulated and elaborated in the tract, Pravda voli monarshei, which has been generally attributed to Feofan Prokopovich. ${ }^{4}$

The results of the law are well-known to us from the series of coups and the constant fears of plots and usurpers that menaced the throne during the eighteenth century. But a law does not operate in a vacuum, and in many respects it continued to reflect the dominant values of the rulers and the court. The utilitarian legitimation continued to dominate in the manifestos, odes, coronation orations, and the symbolism of the court in the eighteenth century. As Cynthia Whittaker has shown, the conception of the "reformertsar" defined the persona of each of the monarchs. In a more practical sense, the absence of a husband for the reigning empress ensured that the well-being of the noble elite would be observed. In either case, a heir was an incubus, menacing the claims based as much or more on achievements than hereditary rights. The heir represented a potential challenge to the claims of having ushered in an "age of gold" or paradise; his existence, posing the suggestion of an alternative, impugned the panegyric mystique. 5

Thus, Elizabeth designated Peter of Holstein her successor, keeping him and his wife Catherine under close watch, but there was already an effort to remove him before she breathed her last. Peter III pointedly omitted mention of his son, Paul, in his decree of accession, which became one of the grounds cited by Catherine II when she deposed him seven months later. Catherine herself may have viewed hereditary monarchy as a necessity to maintain the stability of empire, and she called Paul "heir" in her accession manifesto, but

4 Alain Besançon, Le tsarévitch immolé; la symbolique de la loi dans la culture russe (Paris: Plon, 1967), 109-22; G. Gurvich, "Pravda voli monarshei" Feofana Prokopovicha i eia zapadnoevropeiskie istochniki (Iur'ev: K. Mattisen, 1915); Mikhail Zyzykin, Tsarskaia vlast' $i$ zakon o prestolonasledii $v$ Rossii (Sofia: A. A. Liven, 1924), 72-82.

5 On the age of gold in Russia, see Stephen J. Baehr, The Paradise Myth in Eighteenth Century Russia (Stanford: Stanford University Press, 1991), 38-40, 44-49; and "Fortuna Redux: The Iconography of Happiness in Eighteenth Century Courtly Spectacles," in Great Britain and Russia in the Eighteenth Century: Contacts and Comparisons, ed. A. G. Cross (Newtonville, MA: Oriental Research Partners, 1979), 110. 
confirming her son's rights was something that she never ventured to do, and rumors, probably without substance, suggested that she wished to replace him with her grandson, Alexander, in the last years of her reign. ${ }^{6}$

The utilitarian premise was not an abstract idea but a behavioral principle affirmed in the statements and ceremonies of the imperial court. The metaphor of a god, the performance of classical allegories in the court, were meant to set the ruler apart, to show him or her as the exemplification of eternal values of reason, beauty, and justice, achieved by the reign of a sovereign qua deity. The standard of conduct set by the courts of France and the German principalities hardly emulated the biblical example of the righteous and humble nuclear family. The word "virtue" was used to designate the type of civic behavior consonant with the conduct of the genteel servant of the state and not Christian probity. The escapades of the empresses were hardly matters for discreet silence. Indeed, for those following the example of Louis XIV, the display of lovers was a display of power, Eros and wisdom representing modalities of a classical symbol of transcendence.

The members of the ruler's family were included in the realm of monarchical representation during the eighteenth century. Peter the Great designated the birthdays and name days of members of the imperial family tabel'nye or vysokotorzhestvennye dni, in the manner of German princes. Family members, particularly the heir, were kept safely distant from center stage. Catherine II, who had no claim to the throne except her relationship to her son, included him in major ceremonies, but, especially as he grew older and more threatening, tried to keep him away from the life of the court. The popularity he attracted when he visited Moscow in 1775 with his first wife, the Grand Duchess Natalie Alekseevna, so troubled Catherine that she forbade Paul and his second wife, Grand Duchess Maria Fedorovna, from visiting Moscow after their wedding in $1781 .^{7}$

It was Paul's intention to end this distrust and to introduce a feeling of reverence for the imperial family as dynasty. In the initial days of his reign, he

$6 \quad$ PSZ, Sobranie 1, no. 11390, December 25, 1761; Petr Bartenev, Osmnadtsatyi vek; istoricheskii sbornik (Moscow: T. Ris, 1869), 4: 217; the story of Catherine's reputed intention to remove Paul from the succession is discussed in Oleg Omel'chenko, “Stanovlenie zakonodatel'nogo regulirovaniia prestolonaslediia, 36-46.

7 E. S. Shumigorskii, Imperatritsa Mariia Fedorovna (1759-1828) (St. Petersburg: I. N. Skorokhodov, 1892), 1: 174. 
set about restoring his father, Peter III, to the imperial genealogy, emphasizing his own descent from Peter the Great. Paul staged a macabre ceremony of disinterring Peter III and then crowning his coffin, staging the coronation that his unfortunate father had not hastened to plan. To establish the spousal character of the monarchy, the corpse of Catherine was lifted from her coffin and crowned at the side of her dead husband's coffin. Paul thus made an initial gesture to establish the symbolic role of the imperial family. ${ }^{8}$

This was reflected in the unprecedented form of the new succession law, a covenant between him and the empress Maria Fedorovna, which they had composed in 1788. The decree carried both signatures. The families of the German states often made such family agreements, but they did not issue them from the throne with only two signatures. It thus represented an element of private law given public force by the sovereign will. On the basis of their agreement, the emperor and empress designated their son Alexander heir, "by natural law." The statute introduced what was called the "Austrian system" of succession: male primogeniture of succession, with women following in line only in the absence of a male heir. It required the permission of the ruler for marriages of all those in line for the throne. It also spelled out the organization and conditions of regencies in case the heir had not reached maturity, to prevent a recurrence of the events that had kept Paul himself from the throne in 1762.9

Just as Peter's succession law sought to deal with the peril of an incompetent successor, Paul's sought to ensure "the tranquility of the State," which was "based on a firm law of inheritance upon which every right-thinking person is certain." If Peter's Succession Law was directed at the scheming and perfidious son, Paul's took care to support the claims of the son and to leave no room for the pretensions of an ambitious consort. Love now was to be defined in terms of the dedication and constancy to be exemplified by the members of the imperial family, who identified their destinies with those of the fatherland. The conclusion of the law declared that it provided "proof before the whole World, of Our love for the Fatherland, the love and harmony of our marriage, and love for Our Children and Descendants."

8 Kamerfur'erskii tseremonial'nyi zhurnal, $1796 \mathrm{~g}$ (St Petersburg: Ministerstvo Imperatorskogo Dvora, 185?), 788-91, 821-24, 861-68.

$9 \quad$ PSZ, Sobranie 1, no. 17910, April 5, 1797; B. Nol'de, "Zakony osnovnye v russkom prave," Pravo, No. 9 (1913): 524-26. 
Paul I introduced the legal and symbolic basis for the dynastic monarchy. He also fathered the children who represented and established the dynasty in the first half of the nineteenth century. However, he had been raised in the ways of the eighteenth century, and governed in the circumstances of a court in which such values held little respect. While he sought to restore the respect due to the father of the family, his behavior in this regard followed the pattern of absolute monarchs of the last century. Even before his accession, he had openly taken Catherine Nelidova as mistress, and during his reign he continued to exhibit his infidelities, particularly with Anna Lopukhina, the daughter of his procurator-general, to whom his court had to show the proper signs of respect. Paul's relationship with his son, Alexander, also followed the eighteenthcentury pattern. The distrust between father and son, fed by Catherine's infatuation with her grandson, only grew after her death. Paul suspected, possibly with some grounds, that Alexander was involved in conspiracies to oust him from the throne. In the last two years of his reign, he began to hint of plans to name a new heir. ${ }^{10}$

Neither Alexander nor his younger brother Constantine Pavlovich evinced a predilection for the family or married life. Both were married young, at Catherine's instance, to princesses who quickly wearied them. Constantine's spouse, the Grand Duchess Anna Fedorovna, left Russia in 1801, only five years after their marriage, and his liaisons were numerous and well-known in the court. Alexander, after the first few years, paid little attention to the Empress Elizabeth Alekseevna, who spent most of his reign living a lonely isolated life. His numerous dalliances became the subject of the talk of the European elite, for whose eyes, indeed, many of them were presented. The two daughters Elizabeth bore him died in infancy, and he left no heir.

The Imperial Family at the close of Alexander's reign provided no basis for the sure and reliable political continuity that Paul had envisioned in his law of succession. Constantine had shown reluctance to rule, and in 1820, after divorcing the Grand Duchess Anna, contracted a morganatic marriage with a Polish aristocrat. While not a legal bar to the throne, the marriage

$\overline{10}$ N. Ia. Eidel'man, Gran' vekov, 240-41; Shil'der, Imperator Pavel Pervyi, 287-94; E. P. Karnovich, Tsesarevich Konstantin Pavlovich, 74. The title ostensibly was given as a reward for Constantine's exploits with Suvorov in Italy and Switzerland, but was motivated, in part, by Paul's suspicions of Alexander. I thank Mikhail Safonov for his observations on this matter. 
made him an unlikely candidate to represent the future of the dynasty. Yet Constantine made no open statement of abdication. Alexander, in effect, was forced to act according to the Petrine law and choose his successor. He apparently informed his younger brother, Nicholas, of his decision to designate him heir. But he did so in so secretive and fumbling in a manner that virtually ensured a succession crisis at his death. The manifesto Alexander signed in 1823 was placed, with two letters from Constantine indicating his intention to abdicate, in the State Council, the Senate, the Holy Synod, and the Assumption Cathedral in Moscow. But it had not been promulgated, for reasons that remain inscrutable, and therefore had no legal force. At the moment of Alexander's death, it was known only to Alexei Arakcheev and A. N. Golitsyn, the Metropolitan Filaret, Maria Fedorovna, and possibly to Nicholas himself. ${ }^{11}$ The succession crisis that ensued created the setting for the uprising of December 14, 1825.

\section{Maria Fedorovna, Nicholas Pavlovich, and the Creation of a Dynastic Scenario}

The verbal, visual, and ceremonial presentations of the reign of Nicholas I elaborated the themes of family and dynasty. As in the eighteenth century, Europe provided the model of these values, and Russian monarchs adopted and displayed them in their most consistent and uncompromising forms. The Russian court not only upheld family values but glorified them as attributes of Russian autocracy. Just as Catherine the Great sought to display the Russian empire as the most enlightened and progressive of states, Nicholas I would present it as the exemplar of the familial values of the west. In so doing, he created the dynastic ceremonies and symbolic forms that would rule Russia until the fall of the monarchy.

Clearly, the principal factor promoting an ethic of family solidarity was the specter of revolution: the threat of violent overthrow united father with son and brother, and encouraged shows of affection rather than caution. However, as the examples of Paul and Alexander suggest, the threat was insufficient in itself to instill the norms and patterns of conduct necessary to make the imperial family a central symbol of monarchy. This awaited the reception of

11 S. V. Mironenko, Stranitsy tainoi istorii samoderzhaviia (Moscow: Mysl', 1990), 7485; W. Bruce Lincoln, Nicholas I: Emperor and Autocrat of All the Russias, 22-26. 
the sentimental or early romantic family ethos that arose after the French revolution.

The monarchies that reemerged on the ashes of Napoleonic Europe differed fundamentally from those of the previous century. Once restored to their dominant position in domestic and international affairs, monarchs had to adapt to take into account the new social and political forces awakened during the revolutionary period. The principle of popular sovereignty may have been defeated, but only by calling upon the principle of popular sovereignty itself in rallying national feeling against Napoleon's forces. Nineteenth-century monarchs began to develop ways to represent themselves as the embodiments of national feeling rather than as distant figures whose title to rule stemmed from otherworldly origins. ${ }^{12}$

In certain respects, this change was the next step in the ongoing "desacralization" of European monarchy during the eighteenth century. But the new imagery could be no less elaborate or fanciful than the old. The spinning of personal and historical mythology around the monarchs would continue over the next half-century, elevating them as figures revered or worshiped by the elite and uniting conservative elements of the nation during periods of rapid change. If the monarch could no longer be presented as a god, he or she could be idealized as a better kind of mortal, embodying the features that people admired. Francis II of Austria and especially Frederick-William III of Prussia exemplified what Heinz Dollinger described as the "leadingimage of bourgeois monarchy." Self-effacing, modest, averse to elaborate public presentations, they preferred the comfort of their homes. An affectation of simplicity and equality replaced resplendent majesty as a royal ideal. ${ }^{13}$

While this image may have appealed to "bourgeois" values, European monarchs succeeded in divesting it of egalitarian connotations. They displayed a style of life that may have been bourgeois in its origins, but by the early nineteenth century took on the attributes of a cultural ideal that was portrayed in the literature and art of the period. The new monarchs appeared as immanent rather than transcendent ideals: no longer gifts from the heavens, shedding benefactions on the land, they became exemplars of human conduct,

\footnotetext{
12 See Heinz Dollinger, "Das Leitbild des Burgerkönigtums in der europäischen Monarchie des 19.Jahrhunderts," in Hof, Kultur, und Politik im 19. Jabrbundert, ed. Karl Ferdinand Werner (Bonn: L. Röhrscheid, 1985), 325-62.

13 Ibid., 345-52.
} 
of modest virtue, to be admired by their subjects. This virtue was demonstrated in the monarch's private life, particularly in the realm of the family. European rulers of the eighteenth century had hardly been encumbered by biblical strictures; their nineteenth-century successors were expected to provide models of probity for their subjects.

The increasing autonomy of European bureaucracies encouraged this change. Administrative reforms of the early nineteenth century in Prussia and Austria created a separation between court and bureaucracy, limiting the monarch's powers over administrative institutions and making his symbolic role all the more significant. The Prussian king and the Hapsburg emperor, as centers of aristocratic society and the emerging middle-class elite, epitomized common values of family and religion that appealed to both. The idealization of the monarch's family elevated the ruling dynasty as the historical embodiment of the nation. The sentimental family idyll, thus, was united with the national past to create a myth of the ruler as national ideal.

King Frederick-William III was the model of the effacing king, who exemplified probity, constancy, and piety. In the austere tradition of Prussian royalty, he constructed no immense palaces. The single "palace" he built, at Paretz, hardly suited a court; he told the architect David Gilly, "Everything should be made very simple, just think that you are building not for a prince but an ordinary landlord." He hated public appearances and preferred to walk alone in the woods. He disliked the etiquette of the court and would, unpredictably, ignore it. Only on the parade ground did Frederick-William show a taste for show, but the symbolic value of his military leadership was destroyed by the debacle at Jena in $1806 .{ }^{14}$

Frederick-William also differed from his predecessors in his preference for a virtuous and ideal family life. From the outset of his reign, he presented himself as a model of familial rectitude. At his accession in 1797, he banned his predecessor's mistresses and introduced "almost the style of a German burgher home" to his court. ${ }^{15}$ In addition to this strict morality, his family

14 Thomas Stamm-Kuhlmann, "Der Hof Friedrich-Wilhelms III. von Preussen 1797 bis 1840," in Hof und Hofgesellschaft in den deutschen Staaten im 19. und beginnenden 20. Jahrbundert, ed. Karl Möckl (Boppard am Rhein: H. Boldt, 1990), passim; Hajo Holborn, A History of Modern Germany, 1648-1840 (New York: A. A. Knopf, 1964), 2: $375-76$.

15 Ibid., 375. 
represented an ideal of romantic love to unite the nation. In the aftermath of the French Revolution, he sought to emphasize not the distance between king and nations but their common values. The first issue of the new journal, Jabrbücher der Preussischen Monarchie unter den Regierung von Friedrich Wilbelm III, published in 1798, identified the household of the king, which was "pervaded with the values of true domesticity," with the greater family of the people. ${ }^{16}$

The image of the family united the monarchs and subjects who "entered into this beautiful sphere." The royal family now began to put on display the ideal of love in marriage. An essay in the June 1798 issue of Jabrbücher der Preussischen Monarchie, entitled "Belief and Love," averred, "We have seen in our time that a marvel of transubstantiation has come to pass. Has not the court turned into a family, the throne into heaven, a royal marriage into an eternal union of the heart?"17 Dispossessed of his kingdom after the battle of Jena, forced to accept the reforms instituted by Baron Heinrich Stein, Frederick-William indeed was left with private realm as his only domain. $\mathrm{He}$ claimed no designation from above and even removed the words "from the grace of God" from his title. A painting of "Frederick-William and Queen Louise with their Children" typified the Biedermeier style and became a model for subsequent royal family pictures. ${ }^{18}$

If Frederick-William exemplified paternal feeling and morality, Queen Louise became the model of cultivated, selfless mother and spouse. She combined the elements of "true religiosity" and "true patriotism," epitomizing "the new Prussian wife." She participated in the German literary awakening of her day, though her first language remained French. From the pietism of Gerhardt, she acquired a faith in the spiritual perfectibility of mankind, and, influenced by the theories of Rousseau and Pestalozzi, she tried new approaches to the upbringing of her children. After her death in 1810, shortly after returning from exile to Berlin, she became the subject of a cult of the pure and holy woman. Poets sung her virtues; artists depicted her in terms of the transfiguration and with the features of the Virgin Mary. One adept of this

$16 \quad$ Wulf Wülfing, Karin Bruns, and Rolf Parr, Historische Mythologie der Deutschen (Munich: W. Fink, 1991), 59.

17 Ibid., 60 .

18 Holborn, A History of Modern Germany, 2: 396; Dollinger, "Das Leitbild des Burgerkönigtums," 347. 
cult was the queen's oldest daughter, Princess Charlotte, the future Empress Alexandra Fedorovna of Russia. ${ }^{19}$

Following the example of his father-in-law, Frederick-William III, Nicholas I presented himself as a model of constancy, family values, and simple religious faith. The ruler's superordinate character now derived not from his Olympian achievements, but from the immortality of a dynasty consecrated by God and history. Nicholas created the illusion that the hereditary rights of the dynasty were identical to the historical destinies of the Russian state. Russian imperial presentation, however, did not permit the retiring, private lifestyle of the Prussian king. The monarch as exemplar of private virtue had to be presented in a scenario, an elaborate dramatic performance of domestic dedication, to be admired and imitated by his servitors. The Prussian manner of reserve had to be combined with the French model of constant representation of the monarch as supreme being. Nicholas as stern and righteous paterfamilias became the living manifestation of the moral preeminence of the dynasty.

It was the dowager empress, Maria Fedorovna, who shaped the new scenario and instilled familial values in Nicholas during the last decade of Alexander's reign. Only forty-two years old at Paul's death, Maria Fedorovna retained precedence as the principal figure at the imperial court. While Alexander shunned public appearances, she presided over social functions, family dinners and outings, enforcing the strict etiquette she had observed in Paul's reign. Her palace at Pavlovsk became the social and cultural center of the monarchy. She brought to Russia Protestant notions of the altruistic mission of women and the image of empress as protector of the poor and bereft. She developed the network of foster homes and women's training institutes that she had founded under Paul and encouraged other charitable activities. Maria Fedorovna initiated the tradition of secular charity as a women's concern in Russia. ${ }^{20}$

19 Wülfing et al., Historische Mythologie, 61-78; Stamm-Kuhlmann, "Der Hof FriedrichWilhelms III," 318; Bogdan Krieger, "Erziehung und Unterricht der Konigen Luise," Hohenzollern Jabrbuch (1910): 117-73; A. Th. Von Grimm, Alexandra Fedorovna, Empress of Russia (Edinburg: Edmonston and Douglas, 1870), 1: 51-54.

20 On Maria Fedorovna's creation of a conservative core and promoting conservative national values in her court, see N. N. Mazur, "Iz istorii formirovaniia russkoi natsional'noi ideologii (pervaia tret' XIX v.)" in "Tsep' nepreryvnogo predaniia...": Sbornik pamiati A. G. Tartakovskogo, ed. V. A. Mil'china, A. L. Iurganov (Moscow: Rossiiskii Gosudarstvennyi Gumanitarnyi Universitet, 2004), 196-250. 
Maria Fedorovna shared the religious and ethical values of the Prussian royal house. Her father, a Duke of Württemberg, had been in Prussian service, and she had been educated both in stern patriarchal Protestant values and the French manners and tastes of the German courts of the eighteenth century. As Grand Duchess and Empress, she maintained close family ties, intervening to ensure her parents and siblings' marriage alliances, positions in Prussian and Russian service, and, when necessary, subsidies to avert financial disaster. Her attachment to her parents was encouraged by the sentimental literature of the late eighteenth century. She wrote to them in 1780 that she admired the stoics' ability to remain indifferent to everything, but had no desire to emulate them. "The closer I come to maturity the more I become convinced that the ability to feel nurtures our soul: without it people become savage and cease being people." 21

These sentiments remained with Maria Fedorovna, and she strove to instill them in the members of the Russian imperial family. She introduced the practice of demonstrative mourning for the deceased members of the house and the sense that family bonds only grew stronger after death, aspects of "cult of memory" ascendant in the west. She hallowed the memory of her parents and her husband with two memorials built in the park at Pavlovsk, "To My Parents," and “To My Husband-Benefactor." Thomon's “To My HusbandBenefactor," completed in 1810, is a monument in the form of a Greek temple to her grief for Paul, for whom her feelings had been less than tender. The interior is occupied by Ivan Martos's statue of a mourning wife, her head resting at the side of an urn. The motif of twenty-four weeping faces on the metopes expresses the feeling of sorrow due the father of the dynasty. ${ }^{22}$

Maria Fedorovna tried to show her children the importance of marriage and marital love, but her oldest sons remained deaf to her pleas. She became the family conscience, warning her children that they served as personal models for their subjects. When, in 1803, the Grand Duke Constantine informed her that he wished to terminate his marriage to the Grand Duchess Anna Fedorovna with a divorce, the empress replied with an angry letter. After describing "wounds of the heart" he had inflicted on her, she pointed out the symbolic implications of such a step. It would bring "ruinous consequences for

21 Shumigorskii, Imperatritsa Mariia Fedorovna, 1: 149.

22 Pamiatniki arkhitektury prigorodov Leningrada (Leningrad: Stroiizdat. Leningradskoe otdelenie, 1983), 248-49. 
public morals as well as the lamentable and dangerous temptation for the entire nation." The humblest peasant far from the capital, noting the absence of the Grand Duchess's name next to his in church prayers, would lose respect for the sacrament of marriage and for religious faith itself. ${ }^{23}$

Maria Fedorovna's romantic vision of family relations and connubial love was extolled by her protégé, the poet Vasilii Zhukovksii. Zhukovskii's verse shifted the referent of imperial virtue from a civic ideal, personified in figures of the gods, heroes, or Roman emperors, to the private ideals of the nursery and the hearth. He announced the new motif in an ode to Maria Fedorovna of 1813 .

And where is a more glorious subject for the poet?

Tsaritsa, mother, spouse, daughter of tsars,

The beauty of tsaritsas, the joy of the hemisphere,

Who can find the language proper for it?

Zhukovskii concluded the ode with an evocation of Alexander's imminent return to Russia. He presented the moment as a family, not a mythical event, personal affection expressing imperial glory.

Blessed hour! In the form of martial heroes,

He bends his illustrious head,

The Lord-son before the mother-tsaritsa,

May their love bless this glory-

And withal the saved world lies,

Before your sacred hand!24

Maria Fedorovna’s three youngest children, Nicholas, Michael, and Anna, grew up sharing strong feelings of family solidarity. Ignored by the court, they drew close to each other. They formed their own club, "triopathy," and wore special rings, one of which they gave to their mother as an honorary member. They maintained close ties throughout their lives, what Anna Pavlovna

23 E. P. Karnovich, Tsesarevich Konstantin Pavlovich, 141-48; Shil'der, Imperator Nikolai Pervyi, 1: 128.

24 V. A. Zhukovskii, "Gosudaryne Imperatritse Marii Fedorovne," Polnoe sobranie sochinenii (St. Petersburg: A. F. Marks, 1902), 2:24-25 
described as their "family union." Their later correspondence continued to express an intimacy of feeling and a common purpose that united the members of the house. ${ }^{25}$

Grand Duke Nicholas Pavlovich shared his mother's reverence for the institution of marriage and inclination to regard marital vows as lofty and sacred. When Nicholas showed an interest in Princess Charlotte of Prussia on his return from France in 1814, Maria Fedorovna's esteem for him, previously none too high, rose appreciably. She herself had dreamt of such a match, and in 1809 had discussed the possibility with Queen Louise herself. Princess Charlotte worshipped the memory of the queen, whose bust she later kept in her boudoir. She made herself in her mother's image, adopting her romantic literary tastes and showing the same devotion to family and children. After Louise's death, which had occurred in Charlotte's thirteenth year, she took her mother's place at her father's side and learned at an early age the poise and confidence of royalty. ${ }^{26}$

The writers and artists serving eighteenth- and nineteenth-century Russian monarchs employed the devices of their crafts to present the acts and ceremonies of their sovereign in terms of the monarchical ideals of their age. These devices transformed the transitory appearances of the monarch and the presentations of the court into charismatic moments, expressing the sacred character of imperial rule. The metaphorical mode predominated in eighteenth century texts and illustrations; metaphor transformed the rulers into heroes and heroines, gods and goddesses, establishing a distance between the monarch and his elite, and between the elite and the ruled. The nineteenth-century mode sought to create the illusion of immanence rather than transcendence. Nicholas's person expressed qualities and values integral to this world, or as was claimed, particular to Russia. In this respect, he adopted the manner of Frederick-William III and other western monarchs who appeared as exemplars of virtue and the private life for their subjects. The principal device that produced the illusion of immanence was the metonym, or, more specifically, the synecdoche, which presented the emperor with his family as a concrete expression of the nation.

25 S. W. Jackman, Romanov Relations (London: Macmillan, 1969), 4, 107, and passim.

26 A. Th. Von Grimm, Alexandra Feodorowna, 1: 52-55. 
The texts of Nicholas's reign presented imperial display with new meanings. Rather than expressions of otherworldly spheres where godlike figures cavort and rejoice, ceremonies of the monarch served as microcosms of Russia, representing the attitudes towards authority and modalities of conduct, both official and private, that should prevail in the macrocosm of the empire. ${ }^{27}$ In this equivalence, the macrocosm was defined in terms of the microcosm. The emperor, his family, the dynasty, the army and state epitomized the principal qualities of Russia and represented the whole. Here we see a kinship between political and symbolic representation. Both, Kenneth Burke observed, invoke synecdoche to describe the connection between microcosm and macrocosm. All attempts to "represent" the general will of the people in parliamentary institutions involve a transfer of qualities to the representative body that stands for the people as a whole. ${ }^{28}$ Likewise, the imagery of official nationality claims to reflect the will of the people by making the tsar in his ceremonial appearances the representation of the whole. Nicholas was frequently described as "the embodiment of Russia." The ceremonies of the monarchy embodying Russia were presented to a broadened elite of officials through the official and semi-official press, which became an important medium during the Napoleonic Wars and expanded greatly during Nicholas's reign. ${ }^{29}$

The elevation of the family became apparent from the moment of Nicholas's victory over the Decembrist revolution. On the afternoon of December 14, Nicholas brought his eight-year-old son Alexander before the Sapper battalion, which had saved the imperial family from a threat from the Grenadiers' Regiment. Nicholas made clear that he and the heir were one. He asked the troops to love his son as they loved him. Then he placed

27 On the synecdoche as the expression of the identity of microcosm and macrocosm, see Kenneth Burke, "Four Master Tropes," in his A Grammar of Motives and A Rhetoric of Motives (Cleveland: World, 1962), 508.

28 Ibid.

29 On the semi-official press, see Nurit Schleifman, "A Russian Daily Newspaper and its New Readership: Severnaia Pchela, 1825-1840," Cabiers du monde russe et soviétique, volume 29, No 2 (April-June 1987): 127-44; Charles A. Ruud, Fighting Words: Imperial Censorship and the Russian Press, 1804-1906 (Toronto: University of Toronto Press, 1982), 58-59, 64-65; N. L. Stepanov, “'Severnaia Pchela' F. V. Bulgarina," in Ocherki po istorii russkoi zhurnalistiki i kritiki (Leningrad: Leningradskii gos. Universitet, 1950), 1: 310-11. 
Alexander in the arms of several Cavaliers of the Order of St. George and, at his command, the first officers in each line rushed to the boy and kissed his hands and his feet. ${ }^{30}$

This was the initial demonstration of the new importance of the principle of primogeniture in the life of the imperial house. Nicholas showed that the imperial family rather than the emperor alone represented the spirit and values of autocracy. The scene became emblematic of his reign. It was commemorated in popular pictures and on the bas-relief of the statue Alexander erected to his father in 1858. (Figure 1) The fact that Alexander had stood at his father's side on the day of the rebellion was inscribed in his service list along with the military honors he received on that day.

The family as exemplar of autocracy was a central theme of the visual imagery of Nicholas's reign. An engraving by Thomas Wright, after a painting by George Dawe completed not long after Nicholas's accession, indicates the new importance of the emperor's family for the future of Russian monarchy. A portrait of the Grand Duke Alexander Nikolaevich is set in a large medallion surrounded by flowers, between medallions with portraits of the emperor in uniform and the empress in a décolleté gown (see Article 4, Figure 1). The medallions are placed above and dominate a small sketch of the winter palace. ${ }^{31}$ It was the family of Nicholas that now represented the benefactions of monarchy, symbolized by the sun emanating from the imperial residence.

The domestic happiness of the imperial family was depicted in the mannered poses of English sentimental art by English artists at the Russian court. The paintings of George Dawe, rendered into engravings by his compatriot, Thomas Wright, presented royal personages for the first time in intimate family groups. One of these shows the empress sitting with the infant Olga Nikolaevna in her right arm, and the seven-year-old Alexander Nikolaevich grasping her gown on the left ${ }^{32}$ (see Article 4, Figure 2). Another is a garden scene: Alexander Nikolaevich in sailor suit pushes his little sister Maria, wearing a flowered bonnet, on a swing. Both have the innocent cherubic

\footnotetext{
30 M. Korf, Vosshestvie na prestol Imperatora Nikolaia Iogo (St. Peterburg: II-oe otdelenie sobstvennoi ego Imp. Vel. Kantseliarii, 1857), 220.

31 Shil'der, Imperator Nikolai Pervyi, 1: 297

32 Ibid., 1: 385.
} 


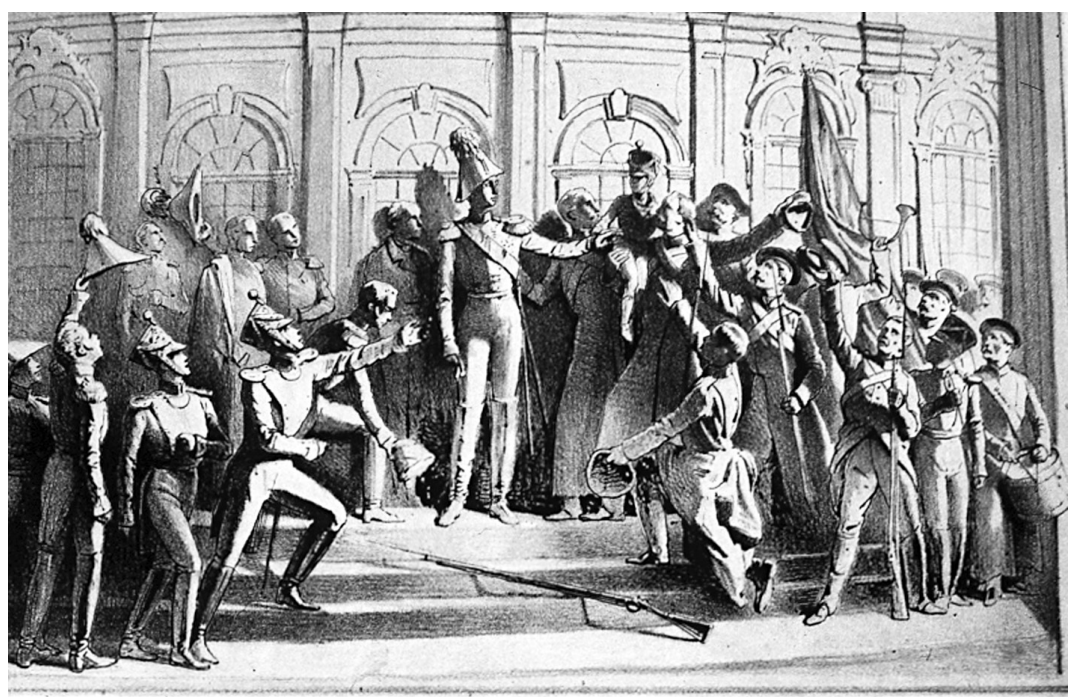

Figure 1.

Bas Relief on Nicholas I Statue. Nicholas I presents his son, Alexander, to the Sapper Battalion, December 14, 1825.

By N. Ramazanov.

Lithograph from Russkii Khudozhestvennyi Listok (1859) 
expressions of nineteenth-century beautiful children. Popular prints took up this theme and showed the emperor adjusting his son's pillow and a family scene at Ekateringof. 33

Upon the death of the Grand Duke Constantine Pavlovich in June 1831, Nicholas issued a decree declaring, that "Our most beloved son" should henceforth be called "Sovereign Heir, Tsesarevich and Grand Duke." (Gosudar' Naslednik, Tsesarevich i Velikii Kniaz') The decree was printed in the press and a series of pictures executed that made Alexander's new title known. ${ }^{34}$ Many lithographs and paintings presented the heir at various stages of his education. A lubok of 1831 shows him in stylized equestrian pose; he wears a cuirassier's uniform, and looks dashing and heroic. At the bottom among his various titles the word tsesarevich is inscribed in bold capitals. In a watercolor by Alexander Briullov, the heir stands at the center of a group of cadets in dress uniform at Peterhof in 1831. He is the tallest and most poised of the boys. His arm is on a staff; beside him is a waving standard. At his foot, sitting under the barrel of a cannon, is his younger brother Constantine Nikolaevich, not yet four years old. Behind, Merder looks on, and an officer in a plumed hat sits on a horse. Lithographed copies of the painting were sent to all military schools. 35

Most important, Nicholas made his family the principal subject of imperial ceremonies. Here I will focus on three: the coronation, the ceremony of the majority of the heir, and Alexander's initiation as the hereditary ataman of the Cossacks of the Don. These ceremonies presented the imperial family as the symbol of the monarchy and likened the types of political subordination to the bonds of dear kin. The paternalistic theme of the tsar as father, protecting his children, now took on a higher moral and literary meaning of sentimental love. The various estates of the realm were gathered to show loyalty as familial act. The "love" of the people became a way to absorb them into a greater family embracing all of Russia.

33 D. A. Rovinskii, Podrobnyi slovar' russkikh gravirovannykh portretov (St. Petersburg: Akademiia Nauk, 1886), 1: 19-20; Imperatorskaia glavnaia kvartira; istoriia gosudarevoi svity; tsarstvovanie Imperatora Nikolaia I (St. Petersburg: M. O. Volf, 1908), 6.

34 Severnaia Pchela, September 7, 1831.

35 Imperatorskaia glavnaia kvartira; istoriia gosudarevoi svity; tsarstvovanie Imperatora Alexandra II (St. Petersburg: R. Golike and A. Vil'borg, 1914), 43. 
The coronation remained the central declaratory ceremony of Russian monarchy through the nineteenth century, consecrating the showing of the character and goals of the monarchy as well as the character of each new reign. But the central theme of the ceremony had shifted markedly during the nineteenth century. Eighteenth-century coronations had celebrated the successful aspirant to the throne as the champion of the general good, legitimizing dubious claims to succession. Nineteenth-century coronations, beginning with Nicholas's, consecrated the monarchy itself, as it was incarnated in the ruling dynasty of which the enthroned emperor was god-chosen representative. Nicholas's immediate family became embodiment of a dynastic tradition that in fact had begun in practice only with Nicholas's reign.

The principal account of Nicholas I's coronation, written by Pavel Svin'in in his journal Otechestvennye Zapiski, presented the entire imperial family as the object of popular affection. In the entry procession to Moscow, Nicholas rode down the avenue flanked by his brother Michael, his brother-in-law, Prince Karl of Prussia, the Duke of Württemberg, and his son, Alexander. ${ }^{36}$ It was Alexander, not the emperor, who was endearing. "The kind Russian people admired the angelic charm of the Heir to the Throne with indescribable rapture." The author went on to point out that this "Royal Child" (Derzhavnyi Mladenets) was particularly dear to Muscovites because he had been born in the Kremlin. A lithograph issued at the time shows the entry into Moscow at the Tver gate. Nicholas is looking smart on a prancing horse next to his brother and the suite; the empress sits in an open carriage, under a parasol. Peasants stand on the buildings waving their caps; joyous people crowd the windows and the balconies. ${ }^{37}$

With Nicholas's coronation, great reviews and maneuvers became an integral part of the coronation celebrations. They assumed the character of ceremonial expressions of the devotion of the military to the imperial family. Military reviews took place frequently during the month between the entry procession and the coronation ceremonies. On July 30, a parade of over fifty thousand troops paid homage to the dowager empress. Grand Duke Alexander rode in his father's suite, on a magnificent steed. The eight-year old galloped past the emperor, charged up and stopped before him to the delight of the

\footnotetext{
36 Ibid., 284.

37 Shil'der, Imperator Nikolai Pervyi, 2: 13.
} 
spectators. The son had paid deference to the father. Then, Nicholas led a detachment before his mother and saluted her, giving recognition to her personal and ceremonial preeminence in the house. ${ }^{38}$ Nicholas took part in large scale maneuvers of the Moscow regiments on August 15 and 16, which were summarized in Svin'in's articles. The maneuvers not only served as a useful exercise for the troops, but provided the large numbers of foreigners and other spectators "a splendid spectacle rare for the residents of Moscow."39

The feeling of the unity of the dynasty was enhanced by the surprise arrival of the Grand Duke Constantine in Moscow. Constantine was peevish as usual, but Nicholas's deferential attention succeeded in calming him by the day of the ceremony. A broadsheet printed at this time shows the three brothers, Nicholas, Constantine, and Michael, riding side by side, with the heir on horseback at Michael's side. On the day of the coronation, a manifesto was issued establishing the rules for a regency and designating Nicholas's "most kind" brother, Michael, regent lest Nicholas die before the heir's majority. ${ }^{40}$

Svin'in's account of the ceremonies in the Assumption Cathedral focused on the members of the family; they and their German relatives are the only participants whom he identifies by name. Svin'in evoked the emotional response of the moment after the investiture of the Emperor and Empress with the regalia: "What rapture (vostorg) seized the hearts of those standing by and of all the inhabitants of Moscow learning by the resounding of the bells and the salvos from the cannons that the Imperial Couple were invested with the purple and crowned!" He remarked how Maria Fedorovna overflowed with rapture, vostorg. "All of Her [Maria Fedorovna's] thoughts, all of Herself, it seemed, was in the heavens from which the blessing descended upon the Head of Her Crowned Son." He then marveled over the feeling with which Nicholas

38 S. S. Tatishchev, Imperator Aleksandr II, 1: 9-10; Maréchal de Marmont, Duc de Raguse, Mémoires (Paris: A l'Expédition [W. Schmidt] 1857), 8: 118-19.

39 "Istoricheskoe opisanie Sviashchennogo Koronovaniia i Miropomazaniia ikh Imperatorskikh Velichestv Gosudaria Imperatora Nikolaia Pavlovicha i Gosudaryni Imperatritsy Aleksandry Fedorovny," Otechestvennye Zapiski (1827), 31: 45-47. Henceforth, "Istoricheskoe opisanie."

40 Imperatorskaia glavnaia kvartira... tsarstvovanie Imperatora Nikolaia I, 219-20; V.I. Zhmakin, "Koronatsii russkikh imperatorov i imperatrits, 1724-1856," Russkaia Starina 38 (1883): 14. The rules designated Grand Duke Michael regent in the circumstance that there was no heir of age to ascend to the throne. PSZ, Sobranie 2, no. 537, August 22, 1826. 
kissed her and his brothers, Constantine and Michael. ${ }^{41}$ Svin'in described the anointment, communion, and recessional in similar elevated terms.

The author of the official coronation album, published in Paris, one Henry Graf, also rhapsodized over the family drama. The embrace between the dowager and the young emperor was "with a visible emotion shared by all those present." But Graf focused primarily on the embrace with Constantine, thus confirming the solidarity of the dynasty for the European audience. "Few of those present could hold back their tears, especially when the Emperor embraced the Tsarevich Grand Duke Constantine, who gathered at this moment the finest fruit of his noble sacrifices." The illustration entitled "the Crowning" of Nicholas presented, instead of the crowning, Constantine embracing Nicholas, who had already been crowned. An act of affection thus was used to show the tsarevich's homage to his younger brother and to dispel the uncertainties about his abdication. The same scene was depicted in a popular print of the time. ${ }^{42}$

The spectacle fulfilled the literary and symbolic expectations of the foreign guests and the Russian official elite. The Duke of Raguse found the unity and devotion of the family "one of the most beautiful things the imagination can conceive." 43 Alexander Benckendorff, the chief of gendarmes and of the Third Section of Nicholas's chancellery, recalled the family coming out of the cathedral: "The incomparable face of the sovereign shone with beauty under the valuable gems of the imperial crown. The young empress and the heir near the empress-mother also attracted everyone's gaze. It was impossible to imagine a more splendid family." Those in attendance also followed the sentimental scenario; they gave their sympathy to the family by weeping-shedding tears of joy to share in the pathos of the triumphant dynasty. Benckendorff remarked on the tears shed when Nicholas handed his sword to Constantine Pavlovich. ${ }^{44}$ State-Secretary Dmitrii Bludov wept unabashedly when Maria Fedorovna embraced the emperor. The ceremony confirmed his religious belief. "I was again assured of the sweetness and the

\footnotetext{
41 "Istoricheskoe opisanie," 31: 196-99.

42 Vues des cérémonies les plus intéressantes du couronnement de leurs majestés Impériales l'empereur Nicholas Ier et l'impératrice Alexandra à Moscou (Paris: Didot, 1828), 5; $I G K$, ts. Nik. I, 222.

43 Marmont, Mémoires, 8: 132-33; E. F. Komarovskii, Zapiski (St. Petersburg: Ogni, 1914), 256-57.

44 Shil'der, Imperator Nikolai Pervyi, 2: 7.
} 
necessity of Faith, that every passion, even the most noble love of Fatherland, not purified by religion, leads only to error and misfortune." 45

Nicholas's coronation introduced scenes of family devotion and reconciliation to the solemn Byzantine rites. The family became a metonymic expression of the constant, devoted, and pure feelings that attached servitors and subjects to the throne. The political bond was sustained by a mythical bond of affection for the imperial family, which the dignitaries of Nicholas's state would be expected to display at the proper occasions. The shedding of tears of joy, and when necessary grief, became obligatory at court ceremonies-a sign of loyalty and sharing in the family life of the tsar, which symbolized his moral and therefore political supremacy. The elite became absorbed in the family of the tsar, a family that exemplified the current European ideal of dynastic monarchy and the current Russian ideal of utter dedication to one's sovereign.

Paul's Law of Succession of 1797 had set the majority of the heir at the young age of sixteen in order to ensure a smooth succession in the event of the early death of the ruling emperor. Alexander was the first heir to reach that age under the law, and to mark the event Nicholas staged a major ceremony on April 22, 1834, introducing a new rite of passage into the life of the imperial court. Pronounced by all Grand Dukes, the oath made the maintenance of autocracy a filial obligation consecrated by God. Metropolitan Filaret of Moscow composed an imposing ceremony in which the son pledged obedience to his father, the autocrat, and the laws of Russia before the assembled elite of the Russian state.

Alexander's oath, written by Mikhail Speranskii, gave emphatic statement to the principles of the unity of family feeling with autocratic government and the maintenance of the inviolability of the prerogatives of the father-sovereign. The purpose of the ceremony, Speranskii asserted, was to confer religious sanction on the heir's future obligations. An oath, he wrote, "is an act of conscience and religion, by which he who vows summons God in witness to the sincerity of his promises and submits himself to His wrath and vengeance in case of violation." The Archpriest Pavskii's instruction to Alexander before the ceremony summoned him to renew the vow to Christ that had taken

45 “Dva pis'ma gr.D.N. Bludova k supruge ego," 1047. 
place at his baptism. "Only a true follower of Christ and sound member of the kingdom of god can be a useful member of the human kingdom." 46

Like the promulgation of the succession law, the first ceremony of majority took place on Easter Sunday, lending it an especially sacred character. It was an important rite of passage for the heir, from a child to his father's helper, joining his father at least symbolically in the exercise of autocratic power. At midnight of New Year's Eve, 1834, Nicholas and Alexandra had told him that the coming year would be the most important of his life. Alexander wrote in his diary, "I feel its importance and will try to prepare myself as much as I can for this moment, for I know that even after it is over, the main task awaits me, that is to complete what has been begun. I ask the All-Powerful Father to give me strength to follow the example of my father in a worthy manner." ${ }^{\prime 37}$

As the day approached, the solemnity of the occasion and its significance for Russia were impressed upon him. On April 16, Nicholas took him on a walk to the Peter-Paul fortress. He told him of the difficulties he would encounter, and urged him to turn to his father and mother for advice. "I will never forget this conversation," Alexander wrote in his diary. Nicholas now initiated him in the cult of ancestors, the immortal unity of the dynasty. At the cathedral, father and son kissed the graves of Paul I and Alexander I and their spouses and the grave of Constantine Pavlovich. Nicholas kissed him and said, in French, "When I lie there, visit me sometimes." "These words touched me so much that I could not contain my tears, and I prayed to myself that the All-Powerful God allow a long life to my dear father." 48 The next day, Alexander received the epaulette and braids of a Flügel-Adjutant of Nicholas's suite.

The ceremony of the oath on April 22, 1834 in the Great Church at the Winter Palace was a major state occasion, described in a detailed account published in Russkii Invalid and Severnaia Pchela. ${ }^{49}$ The ceremony sought to involve the entire state in the family drama of the Russian house; the account referred to those present as "all of Russia." On one side, there stood arrayed the diplomatic corps, State Councilors and Senators. Behind them were Court Officials, members of the Emperor's Suite, Generals, State Secretaries, and

\footnotetext{
46 Tatishchev, Imperator Aleksandr II, 1: 62.

47 “Aleksandr II; Dnevnik, 1834 g." GARF, 678-1-280, 1.

48 Ibid., 21.

49 Severnaia Pchela, April 26, 1834, 365-66; Russkii Invalid, April 27, 1834, 407-08.
} 
others with the right of entry "behind the Cavalier Guards," and the mayor of St. Petersburg. They faced the wives of the diplomatic corps, and ladies of the court. Deputies representing art, science, commerce, and industry were also present. Officers of the guards and lesser civil officials waited in the adjoining halls. From Alexander's teaching staff, Zhukovskii, Edward Collins, and possibly others attended..$^{50}$ The palace was so crowded that Pushkin had difficulty slipping through the back stairways to visit his aunt. ${ }^{51}$

The first part of the event, in the Great Church, was the recitation of the oath as heir to the throne. After the Metropolitan Serafim and other clergy met the imperial family with the cross and holy water, Nicholas led his son to the pulpit, before the life-giving cross and the gospels. Alexander, raising his right hand, delivered the oath. He vowed to serve and obey his father "in all respects" (vo vsem). He promised that he would not spare his life, and would give his last drop of blood, the words of Peter the Great. He would defend the rights and power of "the autocracy of His Imperial Majesty" and would "assist the service of his majesty and the welfare of the state." He pledged to observe all the rulings of the throne and the Laws of the Imperial House. Finally, he called upon God "to guide and teach him in the great service" that had devolved upon him. At this point, he broke down in tears and took several tries to continue. The emperor and empresses then embraced and kissed him.

Metropolitan Filaret in a letter to Prince D. V. Golitsyn described similar feelings. "Kisses and tears reunited father, mother and son. When my own absorption in this inspiring spectacle ended, and my own tears dried, I could see that all present were in tears." 52 Pushkin indicated in his diary that those who did not weep made sure to wipe their eyes as well. ${ }^{53}$ The ceremony was a reprise of the domestic scenario, and a display of feeling, whether real or feigned, showed participation in the spectacle of family solidarity.

50 I. A. Shliapkin, "Iz bumag odnogo iz prepodavatelei Aleksandra II," Starina $i$ Novizna 22 (1917): 15.

51 My description is based on the account published in both Severnaia Pchela, April 26, 1834, 365-66; Russkii Invalid, April 27, 1834, 407-08; Vysochaishe utverzhdennyi tseremonial prisiagi Gosudaria, Naslednika, Aleksandra Nikolaevicha (n.p., n.d.); Tatishchev, Imperator Aleksandr II, 1: 63-65; Grimm, Alexandra Fedorovna, 2: 89-91.

52 Tatishchev, Imperator Aleksandr II, 1: 63-64.

53 A.S. Pushkin, Dnevnik Pushkina, 1833-1835 (Moscow-Petrograd: Gosudarsvennoe izdatel'stvo, 1923), 10. 
After pronouncing the oath, the heir signed it and Count Nesselrode, the Foreign Minister, removed the document for safekeeping in the State Archive. The first part of the ceremony concluded with the singing of a Te Deum, a 301 gun salute from the cannons of the Peter-Paul fortress, and the tolling of the church bells of the capital. Then after the prayer for the long life of the emperor, the imperial family received congratulations from the members of the Holy Synod.

The tears and the family embrace were understood and presented in the sentimental idiom. The report published in Severnaia Pchela and Russkii Invalid, following the sentimental ascription-and prescriptionof emotion, described a general feeling of tenderness, of umilenie, which "penetrated all hearts." It dwelled on the embraces of parents and son. First, Nicholas kissed Alexander three times. Alexander wanted to hug His Mother, but Nicholas reached her first. Then the emperor clasped both of them to him in an embrace. "With this spectacle of all royal and human virtues, a reverent tremor of tenderness [umilenie] touched all hearts." The author of the newspaper accounts compared Alexander's tears to those of Michael Fedorovich when as a boy he had accepted the throne of Russia; the tears showed his understanding of the importance and greatness of the ritual. "May Your tears, Successor of the Great Tsars, be pleasing to God. May they be a guarantee of the goodness of Your soul and the happiness of Your Fatherland." The civil ceremony was followed by an equally imposing military ceremony, the heir's taking of the oath as military officer in the Hall of St. George. The subsequent celebrations, receptions, banquets, and balls continued through Holy Week. ${ }^{54}$

The ceremony of the majority represented the first formal presentation of Alexander as a dynastic symbol, expressing the unity of the governmental and social elite with the dynasty. The rhetoric of the writers close to the throne transformed him into a national symbol as well. A song Zhukovskii wrote for occasion, set to music by Count Mikhail Viel'gorskii, presented Alexander's birth as a national event. From the heights of the Moscow Kremlin, the poem began, "the Russian Land," (Russkaia zemlia), had witnessed Alexander's birth. Years had passed quickly, and now, on the day of the resurrection, the "touching ritual" (umilitel'nyi obriad) was taking place in "Petrograd." Alexander embodied the unity between Moscow and Petersburg, the word for the capital now Russified.

54 Severnaia Pchela, April 26, 1834, 365-66; Russkii Invalid, April 27, 1834, 407-08. 
The ceremony revealed both generational and political solidarity. Father and son, dynasty and people were united in the person of the heir. The son enters the cathedral, raises his hands to heaven,

Before him the father and ruler,

The tsar receives the oath of his son.

Hearken with a blessing,

To the words of his young soul,

And raise your arms to heavens,

Faithful Russia, together with him. .5

Another "Russian Song," by one B. Fedorov, appeared in Russkii Invalid on May 2. Fedorov used a group of boatmen, rowing up the Neva to the palace, as an expression of the joy of the nation as a whole. The boatmen he imagined provided a synecdochical voice of acclamation, on the birthday of "the kind son." They sang to the tsar,

Great is your Imperial joy,

It spreads through all Holy Rus.

You have raised an Heir for Yourself,

ALEXANDER, Your young son is Your hope!

He is the comforting ray of the bright sun,

Our dawn, our light from the great day!

Glory to the Russian sun!

Rejoice Father of the Fatherland! ${ }^{56}$

Alexander's tour of the empire after his nineteenth birthday, from April through December 1837, brought the dynastic scenario to the reaches of the Russian empire. Accompanied by Zhukovskii and an adjutant of Nicholas, S. A. Iur'evich, Alexander covered a distance of over thirteen thousand miles. It was the longest tour of the empire by a tsar or tsarevich, and took him to regions, including parts of Siberia, never visited by a member of the imperial family. His charm in public appearances awakened sentiments that attached the population to the autocracy, drawing the local elites into the family love as a trope for lofty and humane feelings.

54 V. A. Zhukovskii, Sochineniia (St. Petersburg: I. D. Sytin, 1902), 4: 22-23.

55 Russkii Invalid, May 2, 1834, 424.

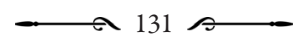


Two events of Alexander's trip assumed especial importance for the role Alexander was to play in his father's scenario-the visit to Moscow in July and August, and his installation as Cossack Ataman in Novocherkassk in October. The Moscow visit linked his personal appeal as heir who was born in Moscow with Russia's historical past. The Metropolitan Filaret emphasized this theme in the welcome speech he delivered upon Alexander's arrival, which was printed in Severnaia Pchela. Alexander, Filaret declared, had now reached Moscow, the resting place of his ancestors. "Here you will come even more into contact with the heart of Russia and its vital force, which is an inherited love for hereditary tsars, repelling in previous centuries so many enemy forces. You will see it in its free play, in those waves of people striving towards You, in those enraptured (vostorzhennykh) gazes and solemn cries." An inherited historical affection was the source of the ruler's authority. "May the love of Russians make your task easy, inspired by love for Russia." 57

According to Nicholas's instructions, Alexander slept in the room where he was born and took historical tours of the city that identified his and the family's fate with Russia's past. Andrei Murav'ev, a specialist on religion and Muscovite antiquities, published an account of his excursions with Alexander to the sites of Moscow and its vicinity. Murav'ev described the young heir's visit to the relics and shrines of his ancestors. In the Novospasskii Monastery, Alexander proceeded slowly beneath a painting of his family tree, "as if attaining at the end of this long genealogical chain that bright link to which he was predestined," Murav'ev wrote. ${ }^{58}$

Another dramatic moment of Alexander's visit to Moscow was his meeting with his mother on August 3, after a separation of three months. An account of the reuniting of mother and son by the popular children's writer Prince Vladimir L'vov appeared in the September 27 issue of Russkii Invalid. L'vov described the scene of a moving embrace. The sun shone with bright rays. The empress and one of his sisters embraced him. "Let foreigners envy us!" L'vov wrote. "Let all Russia enjoy this spectacle and let it be repeated many, many times. Happy is the people whose ruling family gives such an example of love and friendship. Can the tears of joy and the cries of the suffering fail to strike a chord in their hearts?"59

\footnotetext{
56 Severnaia Pchela, 172 (August 3, 1837): 685.

57 A.N. Murav'ev, Vospominaniia o poseshchenii sviatyni Moskovskoi Gosudarem Naslednikom (St. Petersburg: n.p., 1838), 13.

58 Russkii Invalid, September 27, 1837, 960.
} 
The trip culminated with the meeting of father and son at Novocherkassk in the steppes of New Russia, at a new ceremony of initiation that expressed the allegiance of the elite of the Don host not only to the emperor, but to the heir, and the dynasty as a whole. Nicholas had anticipated this event when, in October 1827, he named Alexander, honorary "Ataman of all the Cossack Hosts" and "Chief of the Don Regiment." The position of honorary ataman was presented as a direct personal bond between the imperial family and the Cossacks that brought the Host into the single great family of those loyal to the tsar. The ceremony on October 21 cemented this bond. It likened the devotion of the Cossacks to the devotion of son to father, establishing a rite for all future heirs to throne. ${ }^{60}$

Emperor and heir rode in ceremonial procession into Novocherkassk, the administrative center of the Don Host. The Cossack leaders formed a circle around the cathedral; in the middle, the "appointed" (nakaznyi) Cossack ataman conferred the pernach, one of the maces constituting the Cossack insignia of power, on Nicholas, who then conferred it on Alexander. Nicholas explained the significance of the event. He declared that appointing his son ataman, he was giving a "most valuable pledge (zalog)" of his good will to them. "May this serve as proof of how close you are to my heart. When he replaces me, serve him as loyally as you served my ancestors and me. He will not forsake you." In his diary, Alexander described the ceremony and copied down his father's address. Russkii Invalid reported that "these words were impressed on the heart of each and every one of those present. General, but silent tenderness. (umilenie) This then passed into the joyous cries of pure enthusiasm (vostorg) from the people." 61 The next day, Alexander and Nicholas inspected a review of over 17,000 members of the Host and in the evening attended a ball where the heir took part in several dances.

The domestic scenario introduced in the reign of Nicholas I represented far more than a romantic embellishment to the image of the tsar. It made the family a central symbol of the moral purity of Russian autocracy, which

59 On the myth of "tsar and Cossack," see Robert H. McNeal, Tsar and Cossack, 18551914 (Oxford: MacMillan, 1987), 1-5.

61 Russkii Invalid, November 24, 1837, 1182-83; Severnaia Pchela, November 2, 1837, 989; Tatischev, Imperator Aleksandr II, 1: 89; "Dnevnik V. Kn. Aleksandra Nikolaevicha vo vremia poezdki po Rossii, May 1-December 12, 1837,” 95-96. 
purported to be the purest form of absolute monarchy. The association between domestic morality and autocratic government outlived Nicholas's reign and remained intrinsic to the image of the Russian monarch for the duration of the empire. To violate the principle of autocracy became tantamount to a biblical sin against the father, while violation of family morality would throw into doubt the moral foundations of autocratic rule. Nicholas introduced the forms of behavior, the ceremonies, the feeling of obligation that underlay the notion of Russian dynastic monarchy in the nineteenth century.

The family scenario served various functions in the adaptation of the monarchy to the political circumstances of nineteenth century Europe. The attachment between father and son and between husband and wife elevated the concept of dynastic inheritance to a moral plane and made so elusive a goal appear as part of the national concept of Russian monarchy. The sentimental outpourings of family feeling described by numerous Russian and European writers reaffirmed the common values that identified the Russian sovereign with his western counterparts. Finally, the display of family devotion became a model for the expression of political loyalty. The political bond was personalized. The allegiance to the monarch, no longer demonstrated in the mere witnessing of baroque allegories, now required shows of personal ardor, manifestations of the soul, such as rapture, tenderness, and profuse weeping-a public sharing of what purported to be the innermost feelings of the members of the imperial family. 